\title{
LOKALNA SAMOUPRAVA U BOSNI I HERCEGOVINI
}

Sažetak: Učlanku se daje kratak pregled lokalne samouprave u Bosni i Hercegovini, odnosno u Federaciji Bosne i Hercegovine, Republici Srpskoj i Distriktu Brčko Bosne i Hercegovine. Akcent je stavljen na ustavnopravni položaj lokalne samouprave u BiH, organizaciju i nadležnost jedinica lokalne samouprave te na pravne instrumente zaštite prava na lokalnu samoupravu. Autor ukazuje na specifičnosti sistema lokalne samouprave u BiH te na ulogu i značaj koji lokalna samouprava u BiH, kao razina vlasti koja je najbliža građanima, treba da ima u kreiranju poželjnog životnog ambijenta. S tim u vezi, autor ističe koherentnost interesa na lokalnoj razini, čije ostvarenje je u nadležnosti jedinica lokalne samouprave, kao prednost $i$ adekvatan mogući odgovor na disparatnost interesa na državnoj razini vlasti u BiH. Pored toga, autor ukazuje na određene preduvjete za postizanje istinske lokalne samouprave.

Ključne riječi: $\quad$ Federacija BiH, Republika Srpska, Distrikt Brčko, lokalna samouprava

\section{UVOD}

Ustav Bosne i Hercegovine ${ }^{1}(\mathrm{BiH})$, sastavni je dio (Aneks $4^{2}$ ) Općeg okvirnog mirovnog sporazuma za mir (Dejtonskog mirovnog sporazuma). Ovaj sporazum parafiran je u Daytonu, u vojnoj bazi Wright Patterson 21. 11. 1995. godine gdje su se održavali mirovni pregovori za Bosnu i Hercegovinu, a potpisan je 14. 12. 1995. godine u Parizu. Dejtonski mirovni sporazum je značio prekid ratnih sukoba, značio je mir. Tako da je taj sporazum, uz sve svoje nedostatke,

\footnotetext{
* Mr. sc. Jasmin Hušić, Jedinstveni općinski organ uprave općine Velika Kladuša. Hamdije Pozderca 3, 77230 Velika Kladuša, Bosna i Hercegovina. Adresa e-pošte: jhusic77@gmail.com.

1 Ustav Bosne i Hercegovine, dostupno na: www.ohr.int/?page-id68220. Pristupljeno 19. 2. 2017. godine.

2 Opći okvirni sporazum za mir u BiH sastoji se od sljedećih aneksa: Aneks 1a Sporazum o vojnim aspektima mirovnog rješenja, Aneks $1 b$ Sporazum o regionalnoj stabilizaciji, Aneks 2 Sporazum o granici između entiteta i o drugim pitanjima koja su s tim u vezi, Aneks 3 Sporazum o izborima, Aneks 4 Ustav BiH, Aneks 5 Sporazum o arbitraži, Aneks 6 Sporazum o ljudskim pravima, Aneks 7 Sporazum o izbjeglicama i prognanicima, Aneks 8 Sporazum o povjerenstvu za očuvanje nacionalnih spomenika, Aneks 9 Sporazum o osnivanju javnih poduzeća u BiH, Aneks 10 Sporazum o civilnoj provedbi, Aneks 11 Sporazum o međunarodnim operativnim policijskim snagama (IPTF).
} 
najbolje što se desilo $\mathrm{BiH}$ od 1991. godine. Ovaj sporazum, iako od krucijalne važnosti za BiH nije, još uvijek, objavljen u nekom od službenih glasila $\mathrm{BiH}$.

Danas $\mathrm{BiH}$ čine dva entiteta (Federacija Bosne i Hercegovine i Republika Srpska) i jedan distrikt (Distrikt Brčko BiH). Površina $\mathrm{BiH}$ je 51.209,2 km² a prema zadnjem popisu stanovništva iz 2013. godine u BiH živi 3,531.159 stanovnika.

Federacija Bosne i Hercegovine (u daljem tekstu Federacija $\mathrm{BiH}$ ), kao jedan od entiteta $\mathrm{BiH}$, zauzima 51\% teritorija $\mathrm{BiH}$, odnosno $26.110 \mathrm{~km}^{2}$ i broji 2,219.220 stanovnika. Teritorij Federacije $\mathrm{BiH}$ podijeljen je na deset federalnih jedinica kantona/županija.

Republika Srpska (u daljem tekstu RS) drugi je entitet BiH. Ima površinu od 25.053 km² i broji 1,170.000 stanovnika. U RS nema federalnih jedinica (kantona) već samo entitetska i općinska razina vlasti, tj. lokalna samouprava. U Republici Srpskoj ima 64 jedinice lokalne samouprave i to 57 općina i 7 gradova.

Distrikt Brčko BiH (u daljem tekstu DB) ima površinu od 493 km² i 93.000 stanovnika. Parlamentarna skupština $\mathrm{BiH}$ je na temelju člana X.1. Ustava $\mathrm{BiH}$, na 49. sjednici Predstavničkog doma, održanoj 25. 3. 2009. godine i na 27. sjednici Doma naroda, održanoj 26. 3. 2009. godine donijela Amandman I na Ustav BiH, kojim je izvršeno dodavanje člana VI.4. Ovim članom regulirano je pitanje DB.

Ustav $\mathrm{BiH}$ ne regulira pitanje lokalne samouprave. Tek na jednom mjestu, u članu III.3.b. navode se "administrativne jedinice entiteta". Međutim, Amandmanom I na Ustav BiH utvrđuje se da je DB jedinica lokalne samouprave, da ima vlastite institucije, zakone i propise. Isto tako, Amandmanom I utvrđena je nadležnost Ustavnog suda $\mathrm{BiH}$ da odlučuje o sporovima $\mathrm{u}$ vezi sa zaštitom statusa i nadležnosti $\mathrm{DB}$, što bi podrazumijevalo i zaštitu prava na lokalnu samoupravu.

Obzirom na ovakvu složenost ustavnopravnog sistema $\mathrm{BiH}$ i na, često različite, interese političkih predstavnika u organima vlasti, naročito na državnoj i entitetskoj razini, cilj je ovog rada da ukaže na značaj lokalne samouprave i ulogu koju jedinice lokalne samouprave u $\mathrm{BiH}$ vršenjem svojih nadležnosti treba da imaju u kreiranju poželjnog ambijenta za život građana. Kako u entitetima i u DB postoje određene razlike u konceptu lokalne samouprave, naročito u organizaciji jedinica lokalne samouprave, rad je strukturiran tako da zasebno prikazuje ustavnopravni položaj, organizaciju i nadležnosti jedinica lokalne samouprave u Federaciji $\mathrm{BiH}$, u RS i u DB. S tim u vezi, analizirali smo ustavnopravne, zakonske i statutarne norme propisa kojima su regulirani položaj, organizacija i nadležnosti jedinica lokalne samouprave. Pored toga, tretirali smo i institut zaštite prava na lokalnu samoupravu, kako analizom pozitivno pravnih propisa koji to pitanje reguliraju, tako i sagledavanjem pojedinih slučajeva iz prakse Ustavnog suda Federacije $\mathrm{BiH}$, a koji se tiču zaštite prava na lokalnu samoupravu. Tako utvrđen koncept i položaj jedinica lokalne samouprave, posmatrajući ga u aktualnom političko-pravnom kontekstu sa akcentom na procedure odlučivanja i strateške ciljeve $\mathrm{BiH}$, percipirali smo kao platformu za premoštavanje brojnih različitosti izraženih na višim razinama vlasti. U tom smislu akcentirali smo neka od značajnijih pitanja koja uvjetuju takav pristup lokalnoj samoupravi. 


\section{LOKALNA SAMOUPRAVA U FEDERACIJI BIH}

\subsection{USTAVNOPRAVNI POLOŽAJ LOKALNE SAMOUPRAVE U FEDERACIJI BIH}

Ustav Federacije $\mathrm{BiH},{ }^{3}$ za razliku od Ustava $\mathrm{BiH}$, regulira općinski nivo vlasti, koji, kako je propisano u članu VI.1. u vršenju svojih nadležnosti poduzima mjere u cilju zaštite prava i sloboda koje Ustav Federacije BiH utvrđuje u članovima II.A.1. do 7. i u Aneksu. Također, u članu VI.1.c) garantira se konstitutivnim narodima i pripadnicima ostalih proporcionalna zastupljenost u općinskim organima vlasti. ${ }^{4}$ Dakle, članom IX.11.a) po modelu konsocijativne demokratije garantira se proporcionalna zastupljenost $\mathrm{u}$ javnim institucijama u Federaciji $\mathrm{BiH}$ svim konstitutivnim narodima i grupi ostalih. Konstitutivni narodi su bili samo Bošnjaci i Hrvati, ali je Ustavni sud BiH Odlukom broj U-5/98-III ${ }^{5}$ utvrdio da su na području Federacije $\mathrm{BiH}$ i Srbi konstitutivni narodi.

Ustav Federacije BiH ne utvrđuje nadležnosti općinskih vlasti kao što to čini kod federalnih i kantonalnih vlasti. Međutim, u članu VI.2. utvrđeno je da se u općini ostvaruje lokalna samouprava te da općina ima statut koji mora biti usklađen kako sa Ustavom Federacije BiH, tako i sa Ustavom i zakonima kantona.

Ustavom se, dalje, reguliraju nadležnosti i izbor općinskog vijeća i općinskog načelnika te osnivanje i nadležnosti općinskih sudova. Tako se u članu VI.3. propisuje da općina ima općinsko vijeće i općinskog načelnika. Oba organa i općinski načelnik i općinsko vijeće biraju se, kako se utvrđuje u Ustavu, na demokratskim, neposrednim i tajnim izborima na mandat od četiri godine. Bitno je naglasiti da je istim članom (VI.3.) propisano da općinski načelnik i predsjedavajući općinskog vijeća ne mogu biti iz istog konstitutivnog naroda niti iz reda ostalih. Ta mogućnost je ostavljena samo u općinama u kojima jedan konstitutivni narod čini više od $80 \%$ stanovnika prema posljednjem popisu stanovnika u $\mathrm{BiH}$.

U članu VI.4. utvrđuju se nadležnosti općinskog vijeća da usvaja statut i općinski budžet, da donosi propise o oporezivanju te da na druge načine osigurava potrebno financiranje koje nije osigurala kantonalna ili federalna vlast. Također, općinsko vijeće se ovlašćuje, općom klauzulom, da donosi propise u izvršavanju općinskih nadležnosti, da poduzima normativne aktivnosti koje je potrebno u izvršavanju nadležnosti općine. Dalje, u članu VI.5. propisuje se da općinsko vijeće "stvara uvjete za izbor općinskog načelnika i donosi svoj poslovnik". Poslovnik mora biti usklađen sa federalnim i kantonalnim zakonom. Istim članom se utvrđuje javnost rada općinskog vijeća, odnosno javnost zasjedanja općinskog vijeća, osim u izuzetnim okolnostima koje općinsko vijeće može predvidjeti u svom poslovniku, kao i da se vodi zapisnik o donesenim odlukama.

Ustav Federacije BiH, pored nadležnosti općinskog vijeća, utvrđuje i nadležnosti općinskog načelnika. Tako u članu VI.6. utvrđuje se da je općinski načelnik nadležan za imenovanje i smjenjivanje općinskih službenika, zatim za provođenje općinske politike, izvršavanje općin-

3 Ustav Federacije Bosne i Hercegovine, Službene novine Federacije Bosne i Hercegovine, broj 1/1994, 13/1997, 16/2002, 22/2002, 52/2002, 63/2003, 9/2004, 20/2004, 33/2004, 71/2005, 72/2005, 88/2008.

4 Zastupljenost odražava popis stanovništva iz 1991. godine do potpune provedbe Aneksa 7. u skladu sa članom IX.11.a. Ustava Federacije BiH. 
skih propisa i delegiranih ili prenesenih nadležnosti općini od kantonalnih ili federalnih vlasti. Dalje, utvrđuje se da je općinski načelnik nadležan za osiguranje saradnje općinskih službenika sa ombudsmenima te da podnosi izvještaj općinskom vijeću i javnosti o provođenju općinske politike i svojih aktivnosti.

Pored općinskog vijeća kao predstavničkog tijela (vlasti) i općinskog načelnika kao izvršne vlasti u glavi VI Općinske vlasti, Ustavom Federacije BiH konstituira se i sudska vlast, odnosno općinski sudovi.

U poglavlju VI.A. Ustava Federacije BiH regulirane su gradske vlasti. Ovo poglavlje dodano je amandmanom XVI na Ustav Federacije BiH. Kasnije je i ovo poglavlje mijenjano amandmanom XXV, amandmanom LXXXVII i amandmanom C. Iza ovog poglavlja, amandmanom XXVI, dodano je još jedno poglavlje koje se odnosi na grad, a to je poglavlje VI.B. Organizacija Sarajevo.

Nešto kasnije, Odlukom Visokog predstavnika u BiH Paddyja Ashdowna ${ }^{6}$ proglašeni su amandmani XCV-CII. Ovim amandmanima, točnije amandmanom CI dodan je novi član VI.C. Organizacija Mostara.

Također, u poglavlju VI.A. Ustava Federacije BiH utvrđuje se mogućnost da se u skladu sa zakonom za područje dvije ili više općina formira grad kao jedinica lokalne uprave i samouprave. Ustav propisuje i nadležnosti odnosno odgovornosti grada koje obuhvaćaju: financije i poresku politiku, zajedničku infrastrukturu, urbanističko planiranje, javni promet te druge nadležnosti koje gradu povjeri kanton, odnosno prenesu općine.

Grad, kako je utvrđeno Ustavom Federacije BiH, ima statut, gradsko vijeće i gradonačelnika. Gradsko vijeće, koje čine vijećnici iz općina koje ulaze u sastav grada, usvaja statut grada, bira gradonačelnika, donosi budžet grada i propise u izvršavanju ovlaštenja. Gradonačelnik imenuje i smjenjuje gradske funkcionere, provodi gradsku politiku i izvršava gradske propise, osigurava saradnju gradskih funkcionera sa ombudsmenima te podnosi izvještaj gradskom vijeću i javnosti.

Dakle, amandmanom XVI na Ustav Federacije BiH date su ustavne pretpostavke za formiranje gradova kao jedinica lokalne uprave i samouprave.

Pored Grada Sarajeva i Grada Mostara, odnedavno uspostavljena su još četiri grada. Dakle, 2014. godine Parlament Federacije BiH donio je Zakon o gradu Bihaću, Zakon o gradu Tuzli, Zakon o gradu Zenici i Zakon o gradu Široki Brijeg. Ovi gradovi uspostavljeni su u skladu sa uvjetima utvrđenim u članu 5. stav 3. Zakona o principima lokalne samouprave u Federaciji Bosne i Hercegovine (u daljem tekstu: ZOPLS), ${ }^{7}$ kojim je utvrđeno da grad predstavlja sjedište kantona i u slučaju da ne ispunjava uvjete koji su utvrđeni u članu 5. stav 2. ZOPLS-a. Dakle, sjedište kantona je grad u smislu ZOPLS-a i kad ne ispunjava uvjete za uspostavljanje grada, tj. da predstavlja urbanu, infrastrukturnu cjelinu povezanu svakodnevnim potrebama stanovništva, koja ima najmanje 30.000 stanovnika, odnosno da u užem gradskom središtu živi najmanje 10.000 stanovnika. U parlamentarnoj proceduri još su tri zakona kojima se općinama Cazin, Livno i Goražde utvrđuje status grada. Ovi zakoni su već doneseni u Predstavničkom domu i upućeni u Dom naroda Parlamenta Federacije BiH.

6 Odluka kojom se proglašavaju izmjene i dopune Ustava Federacije Bosne i Hercegovine, Službene novine Federacije Bosne i Hercegovine, broj 9/2004.

7 Zakon o principima lokalne samouprave u Federaciji Bosne i Hercegovine, Službene novine Federacije Bosne i Hercegovine, broj $49 / 2006$. 


\subsection{ORGANIZACIJA I NADLEŽNOST JEDINICA LOKALNE SAMOUPRAVE U FEDERACIJI BIH}

Jedinice lokalne samouprave su, kako je to utvrđeno ZOPLS-om, općine i gradovi. Ovim Zakonom, kada je riječ o nadležnosti jedinica lokalne samouprave, nije učinjena distinkcija između općine i grada, odnosno između pojedinih jedinica lokalne samouprave. Stoga lokalna samouprava u Federaciji BiH ima monotipski ustroj. Međutim, ustavi pojedinih kantona utvrdili su mogućnost razlikovanja općina po nadležnostima. Tako Ustav Kantona Sarajevo i Ustav Bosansko-podrinjskog kantona (Kantona Goražde) utvrđuju da općine mogu imati različite nadležnosti zavisno od globalne politike funkcioniranja i razvoja Kantona te od ekonomskog, prostornog i drugog položaja pojedinih općina. Time je ostavljena mogućnost politipskog ustroja općina na području ovih kantona.

Na području Federacije BiH formirano je ukupno 80 jedinica lokalne samouprave, uključujući i Grad Sarajevo koji je jedina jedinica lokalne samouprave u Federaciji BiH koja se sastoji od više općina (Centar, Novi Grad, Novo Sarajevo i Stari Grad). Prosječna veličina jedinica lokalne samouprave u Federaciji $\mathrm{BiH}$ je $330,5 \mathrm{~km}^{2}$, a prosječan broj stanovnika je 28.286. Sa ovim brojem stanovnika i površinom općine u Federaciji BiH značajno su iznad prosjeka zemalja članica EU-a. Općine u EU-u u prosjeku imaju 19.034 stanovnika i površinu od 270,28 km². Da li treba dati prednost organiziranju većih ili manjih općina, izuzetno je značajno pitanje naročito sa aspekta mogućnosti i efikasnosti zadovoljavanja potreba građana. Ovim pitanjem su se bavili brojni autori kao npr. Ivanišević, ${ }^{8}$ Pavić, ${ }^{9}$ Koprić ${ }^{10}$ i dr. Činjenica je da veći broj europskih zemalja u zadnje vrijeme kroz reformske procese nastoji smanjiti broj lokalnih jedinica. Tako Pavić ${ }^{11}$ naglašava da sve više dolazi do procesa spajanja, odnosno amalgamiranja te da $u$ zemljama Europe prevladava tendencija prema većim lokalnim jedinicama. Također, Koprićc ${ }^{12}$ ukazuje na trend stvaranja većih i jačih lokalnih jedinica u razvijenim zemljama te predlaže smanjenje broja općina u Hrvatskoj. U BiH kao i u drugim europskim zemljama postoje velike razlike između pojedinih jedinica lokalne samouprave, kako u pogledu broja stanovnika, tako i u pogledu površine i naravno financijske (ekonomske) moći. Tako primjerice općina Trnovo ima 1.522 stanovnika, a površinu teritorija $338 \mathrm{~km}^{2}$, dok općina Novi Grad Sarajevo broji 118.553 stanovnika i ima površinu od $47 \mathrm{~km}^{2}$. Isto tako, općina Glamoč ima površinu od 1.033 $\mathrm{km}^{2}$, a na njenom prostoru živi svega 3.860 stanovnika.

Jedan broj općina koje imaju izrazito malu površinu ili broj stanovnika oformljen je uslijed neprirodnog povlačenja linije razgraničenja između entiteta Federacije BiH i RS kojom su rascijepljene površine prijeratnih općina. Posljedica toga su općine od svega desetak kvadratnih kilometara koje nemaju potencijal za potpuno i kvalitetno obavljanje svojih nadležnosti. Sve to ukazuje da je potrebno u što skorije vrijeme iznaći rješenje koje će značiti teritorijalni preu-

8 Ivanišević, Stjepan, Stupnjevanje lokalnih samoupravnih jedinica, Hrvatska javna uprava, broj 3, 2009., str. 669.-722.

9 Pavić, Željko, Veličina lokalnih jedinica - europske tendencije i hrvatske nedoumice, Hrvatska javna uprava, broj 1, 2010., str. 81.131.

10 Koprić, Ivan, Prijedlozi za reformu lokalne i regionalne samouprave u Hrvatskoj, Hrvatska javna uprava, broj 4, 2010., str. $941 .-959$.

11 Pavić, Željko, op. cit. u bilj. 9.

12 Koprić, Ivan, op. cit. u bilj. 10. 
stroj pojedinih općina kojim će se stvoriti pretpostavke za samostalno svakodnevno efektivno funkcioniranje tih općina.

\subsubsection{Nadležnost jedinica lokalne samouprave u Federaciji BiH}

Nadležnost jedinica lokalne samouprave detaljno se, sistemom enumeracije, utvrđuje u ZOPLS-u. Tako se u članu 8. ZOPLS-a, pored ostalog, kao vlastite nadležnosti jedinica lokalne samouprave utvrđuje nadležnost u oblasti ljudskih prava, zatim usvajanje i donošenje budžeta, programa i planova razvoja te stvaranje uvjeta za razvoj i zapošljavanje. Također, kao vlastite nadležnosti jedinica lokalne samouprave, ZOPLS utvrđuje uređenje prostora i zaštitu okoline, zatim donošenje i usvajanje prostorno planske dokumentacije, stambenu politiku, raspolaganje građevinskim zemljištem i imovinom jedinice lokalne samouprave te utvrđivanje politike upravljanja prirodnim resursima kao i pravo na raspodjelu sredstava koja su ostvarena njihovim korištenjem.

Pored navedenog ZOPLS utvrđuje nadležnosti jedinica lokalne samouprave u oblastima koje su uobičajene za lokalne zajednice kao što je komunalna infrastruktura, snabdijevanje vodom, otpadne vode i komunalni otpad, javna čistoća, gradska groblja, lokalni putevi i mostovi; ulična rasvjeta; parkirališta; parkovi; lokalni javni prijevoz; predškolsko obrazovanje; osnovno obrazovanje; kultura i sport.

Osim toga, ZOPLS kao vlastite nadležnosti jedinica lokalne samouprave propisuje ocjenjivanje kvaliteta pružanja usluga od strane javnih ustanova u oblastima zdravstva, socijalne zaštite, obrazovanja, kulture i sporta. Općine i gradovi, također, prema svojim mogućnostima mogu financijskim sredstvima pomoći takve javne ustanove u vršenju njihovih nadležnosti kako bi se podigla kvaliteta usluga u skladu sa potrebama građana. Jedinice lokalne samouprave nadležne su i za praćenje i analizu stanja javnog reda i mira, sigurnosti, ali i za osiguranje zaštite i spašavanja od elementarnih nepogoda kao i prirodnih katastrofa. Općine i gradovi su naravno nadležni za formiranje vlastitih inspekcija za vršenje inspekcijskog nadzora nad provođenjem propisa iz nadležnosti lokalne samouprave. Također, reguliranje naknada, doprinosa i taksa iz nadležnosti jedinice lokalne samouprave te raspisivanje referenduma i javnog zajma kao i donošenje odluke o zaduženju u nadležnosti je jedinica lokalne samouprave. Pored svega navedenog u nadležnosti jedinica lokalne samouprave u Federaciji BiH je lokalni radio i televizija, vođenje evidencija o ličnim stanjima građana, birački spiskovi, katastar zemljišta, mjesna samouprava i zaštita životinja. ZOPLS u istom članu utvrđuje da se jedinice lokalne samouprave imaju pravo baviti svim pitanjima koja su od lokalnog značaja, a pri tom nisu isključena iz njenih nadležnosti ili dodijeljena u nadležnost drugoj vlasti.

\subsubsection{Organi jedinica lokalne samouprave u Federaciji BiH}

Organi jedinica lokalne samouprave su općinsko vijeće ili gradsko vijeće kao predstavničko tijelo i općinski načelnik u općinama ili gradonačelnik u gradu kao izvršni organ.

Odnos između ova dva organa ZOPLS u članu 16. regulira kao odnos koji se zasniva na "principima međusobnog uvažavanja i suradnje". Svaki od organa odgovoran je za realizaciju vlastitih nadležnosti, a dijele odgovornost, odnosno suodgovorni su za funkcioniranje jedinica 
lokalne samouprave. Dakle općinsko vijeće i općinski načelnik nisu u odnosu subordinacije, oba organa biraju se neposredno od strane svih građana koji imaju biračko pravo. Do 2004. godine, kada je izmijenjen Izborni zakon $\mathrm{BiH}$ i donesen Zakon o neposrednom izboru načelnika u Federaciji BiH, općinskog načelnika biralo je općinsko vijeće iz reda svojih članova, što je značilo podređenost općinskog načelnika prema općinskom vijeću.

Općinsko vijeće je nadležno za donošenje odluka na općinskom nivou kao što su statut, budžet, prostorni planovi (prostorni plan, urbanistički plan, regulacioni i zoning planovi i urbanistički projekti), odluke koje se odnose na općinske takse i naknade, odluke o zaduživanju i upravljanju općinskom imovinom, odluke o udruživanju sa drugim jedinicama lokalne samouprave, o raspisivanju referenduma. Općinsko vijeće je nadležno i za osnivanje javnih poduzeća i ustanova na općinskom nivou, organizaciju mjesne samouprave (formiranje mjesnih zajednica), te utvrđivanje naziva ulica, trgova i dijelova naselja.

Općinski načelnik kao izvršni organ u okviru svojih nadležnosti utvrđenih u članu 15. stav 1. ZOPLS-a, predstavlja i zastupa općinu; donosi akte iz svoje nadležnosti; izrađuje i vijeću podnosi na usvajanje odluke i druge opće akte (budžet, ekonomske planove, razvojne planove, prostorno planske dokumente i dr.); provodi politiku općine; utvrđuje organizaciju službi za upravu i drugih službi općine; donosi pravilnik o unutrašnjoj organizaciji općinskih službi. Pored toga u nadležnosti općinskog načelnika je i ostvarivanje saradnje sa drugim jedinicama lokalne samouprave, organizacijama i institucijama. Općinski načelnik je, iako nije sa općinskim vijećem u odnosu subordinacije, ipak dužan izvještavati ovo predstavničko tijelo o svojim aktivnostima i radu organa uprave, odnosno općinskih službi.

\subsection{ZAŠTITA PRAVA NA LOKALNU SAMOUPRAVU U FEDERACIJI BIH}

ZOPLS u članu 2. definira lokalnu samoupravu na način kako je to učinjeno i Europskom poveljom o lokalnoj samoupravi (EPLS). U određenju lokalne samouprave ZOPLS lokalnu samoupravu određuje kao "pravo i osposobljenost jedinica lokalne samouprave". Zaštitu tog prava osigurava Ustavni sud Federacije BiH. Član IV.C.10. Ustava Federacije BiH, koji utvrđuje nadležnost Ustavnog suda Federacije BiH dopunjen je Amandmanom XCVI. Ovim Amandmanom se utvrđuje nadležnost Ustavnog suda da odlučuje o zahtjevu za zaštitu prava na lokalnu samoupravu. Zahtjev za zaštitu prava na lokalnu samoupravu mogu podnijeti općine i gradovi i udruženja općina i gradova Federacije BiH.

U većini slučajeva koji su vođeni pred Ustavnim sudom Federacije BiH po zahtjevu za zaštitu prava na lokalnu samoupravu, a u kojima je utvrđena povreda tog prava, Ustavni sud Federacije $\mathrm{BiH}$ pozivao se na odredbe EPLS-a. Uglavnom su se utvrđene povrede odnosile na nekonzultiranje jedinica lokalne samouprave (član 4. tačka 6. EPLS-a) i na povredu prava na izvore financiranja jedinica lokalne samouprave.

Naime, članom VII.3. Ustava Federacije BiH utvrđeno je da međunarodni ugovori i drugi sporazumi koji su na snazi u BiH i Federaciji BiH, kao i opća pravila međunarodnog prava jesu dio zakonodavstva Federacije $\mathrm{BiH}$ te utvrđuje i primat međunarodnih ugovora i sporazuma nad zakonodavstvom Federacije $\mathrm{BiH}$. $\mathrm{BiH}$ je ratificirala 1994. godine EPLS. Tako da EPLS predstavlja izuzetno značajan dokument, naročito sa aspekta zaštite prava na lokalnu samoupravu. Narav- 
no, garanciju prava na lokalnu samoupravu daje i ZOPLS na kojem Ustavni sud, pored Ustava Federacije BiH i EPLS-a, zasniva svoje odluke u postupcima zaštite prava na lokalnu samoupravu.

\section{LOKALNA SAMOUPRAVA U RS}

\subsection{USTAVNOPRAVNI POLOŽAJ OPĆINA U RS}

Ustav Republike Srpske (Ustav RS) ${ }^{13}$ u poglavlju VI teritorijalna organizacija, član 102. utvrđuje da se sistem lokalne samouprave uređuje zakonom. Istim članom, Ustav RS propisuje određene nadležnosti općine taksativno ih navodeći te općom klauzulom ostavlja mogućnost utvrđivanja i drugih nadležnosti u zakonu i statutu općine. Ustav RS na ovom mjestu (član 102.) određuje kao nadležnosti općine: donošenje programa razvoja, urbanističkog plana, budžeta i završnog računa; obavljanje komunalnih djelatnosti; gradsko građevinsko zemljište i poslovne prostore; lokalne puteve i ulice; kultura, obrazovanje, zdravstvena i socijalna zaštita, fizička kultura, informiranje, zanatstvo, turizam i ugostiteljstvo, zaštita životne sredine; izvršava zakone i druge propise te formira organe, organizacije i službe za svoje potrebe.

Kada je riječ o nadležnostima, Ustav RS u odnosu na Ustav Federacije BiH dosta detaljnije utvrđuje nadležnosti općina. Međutim, Ustav RS uopće ne regulira organizaciju općina kao što ne utvrđuje izričito da se lokalna samouprava ostvaruje u općinama, što je slučaj sa Ustavom Federacije BiH. Dmičić, ${ }^{14}$ smatra da bi vjerojatno bilo bolje da Ustav ne utvrđuje decidno nadležnosti jer se djelokrug jedinica lokalne samouprave konstantno mijenja. Ipak, smatramo da ustavno definiranje nadležnosti jedinica lokalne samouprave snažnije potvrđuje značaj lokalne samouprave u vertikalnom ustroju vlasti i daje snažniju garanciju tako utvrđenog spektra nadležnosti. Naime, pored taksativnog pobrajanja nadležnosti Ustav RS ne zatvara djelokrug jedinica lokalne samouprave, nego općom klauzulom ostavlja mogućnost dodatne regulacije nadležnosti, pored Ustava, zakonom i statutom, što je dobro normativno rješenje za jednostavniju prilagodbu i aktualizaciju nadležnosti jedinica lokalne samouprave. Slično, i Dmičićc ${ }^{15}$ ističe kako ustavotvorac tu situaciju decidnog utvrđivanja nadležnosti u Ustavu može da preduprijedi tako što će utvrditi da jedinice lokalne samouprave, pored onog što je Ustavom utvrđeno, obavljaju i druge poslove utvrđene Ustavom, zakonom i statutom. Što je u slučaju Ustava RS i učinjeno.

\subsection{ORGANIZACIJA I NADLEŽNOST JEDINICA LOKALNE SAMOUPRAVE U RS}

Zakon o lokalnoj samoupravi Republike Srpske (u daljem tekstu ZLSRS), ${ }^{16}$ smatramo, utvrđuje potpunije i kvalitetnije sadržaj pojma lokalne samouprave u odnosu na ZOPLS. Ovo na-

13 Ustav Republike Srpske, Službeni glasnik Republike Srpske, broj 21/1992 - prečišćeni tekst, 28/1994, 8/1996, 13/1996, 15/1996, 16/1996, 21/1996, 21/2002, 26/2002, 30/2002, 31/2002, 69/2002, 31/2003, 98/2003, 115/2005, 117/2005.

14 Dmičić, Mile, Modernizacija, profesionalizam i usavršavanje lokalne samouprave u sistemu ustavnih promjena u BiH, Moderna uprava, Agencija za državnu upravu Republike Srpske, Banja Luka 2008.

15 Ibid.

16 Zakon o lokalnoj samoupravi Republike Srpske, Službeni glasnik Republike Srpske, broj 97/2016. 
ročito iz razloga jer se lokalna samouprava određuje kao pravo građana za razliku od ZOPLS-a kojim se utvrđuje da je lokalna samouprava pravo jedinica lokalne samouprave (tj. općina i gradova).

Kada je riječ o nadležnostima jedinica lokalne samouprave u RS, pored opće klauzule kojom je općinama utvrđeno pravo da reguliraju sva pitanja od lokalnog značaja, a koja nisu isključena iz nadležnosti općine ili dodijeljena u nadležnost drugoj razini vlasti, ZLSRS propisuje nadležnosti taksativno i dosta detaljnije u odnosu na ZOPLS. Tako utvrđuje nadležnosti u oblastima: organiziranja rada i upravljanja jedinicom lokalne samouprave; pružanja usluga; prostornog planiranja i građenja; stambeno-komunalnih djelatnosti; kulture; osnovnog, srednjeg i visokog obrazovanja; zdravstvene i socijalne zaštite stanovništva; brige o djeci i omladini; sporta i fizičke kulture; turizma, ugostiteljstva, zanatstva i trgovine; zaštite prirodnih dobara i životne sredine; zaštite od elementarnih i drugih većih nepogoda; ljudskih prava i sloboda građana i individualnih i kolektivnih prava pripadnika nacionalnih manjina. U okviru svake od navedenih oblasti ZLSRS detaljno navodi nadležnosti jedinica lokalne samouprave.

Što se tiče organa jedinica lokalne samouprave u RS, zakonom se utvrđuju skupština grada ili općine kao predstavničko tijelo i gradonačelnik ili načelnik općine kao izvršni organ. Oba organa biraju se neposredno od strane svih građana koji imaju pravo glasa, a mandatni period traje četiri godine. Odnos između ova dva organa uređen je kao i u Federaciji $\mathrm{BiH}$ na principima međusobnog uvažavanja saradnje.

Nadležnosti skupštine općine ZLSRS utvrđuje dosta detaljno. Tako određuje da je općina nadležna da donosi statut, budžet, odluke i druge opće akte i daje njihovo autentično tumačenje. Zatim, usvaja financijske izvještaje, donosi planove i programe razvoja i dokumente prostornog uređenja, kao i program uređenja građevinskog zemljišta. Također, ZLSRS utvrđuje nadležnost općina za reguliranje u oblasti kulture i obrazovanja, zdravstvene i socijalne zaštite, sporta, zanatstva te u oblasti ugostiteljstva i turizma, kao i zaštite životne sredine.

Skupština isto tako utvrđuje komunalne takse i druge javne prihode na lokalnom nivou te daje suglasnost na cijenu komunalne usluge. ZLSRS određuje kao nadležnost skupštine reguliranje u oblasti civilne zaštite, zatim raspolaganje imovinom jedinice lokalne samouprave, utvrđivanje naziva ulica, trgova i naselja te proglašenje praznika jedinice lokalne samouprave. Pored toga skupština je nadležna za donošenje odluka o upotrebi simbola jedinice lokalne samouprave, o članstvu jedinice lokalne samouprave u savezu općina i gradova i drugim organizacijama, o proglašenju počasnih građana i drugim nagradama i priznanjima. Sva imenovanja i razrješenja na određene položaje i pozicije na općinskoj razini kao što su pozicije predsjednika skupštine, potpredsjednika skupštine, zamjenika gradonačelnika, odnosno načelnika općine i članove stalnih i povremenih radnih tijela skupštine, sekretara skupštine i načelnika odjeljenja, odnosno službi u nadležnosti su skupštine. Skupština, također, odlučuje o zaduženju jedinice lokalne samouprave, usvaja poslovnik o radu i etički kodeks skupštine.

U nadležnosti skupštine je i razmatranje izvještaja o radu gradonačelnika, odnosno načelnika općine, razmatranje informacija o stanju javnog reda i mira, sigurnosti građana i imovine na području jedinice lokalne samouprave. Skupština može pokrenuti inicijativu za opoziv gradonačelnika, odnosno načelnika općine, u skladu sa zakonom kojim se uređuje izbor gradonačelnika, odnosno načelnika općine. Skupština ima utvrđene nadležnosti i u oblasti praćenja i nadzora javnih poduzeća i ustanova od lokalnog značaja, tj. kojima je osnivač općina. To čini 
putem razmatranja izvještaja o radu u organima poduzeća i ustanova, odlučivanje o raspolaganju kapitalom, imenovanje i razrješenje direktora i upravnih odbora u skladu sa zakonom. Skupština također odlučuje o javnom zajmu i samodoprinosu, a donosi i odluku o raspisivanju referenduma na lokalnom nivo.

Kao što se može zaključiti, ZLSRS vrlo iscrpno utvrđuje nadležnosti skupštine općine, tako da ostavlja vrlo malo prostora za statutarno uređenje ovog pitanja.

Isti pristup detaljnog reguliranja nadležnosti ZLSRS ima i kod utvrđivanja nadležnosti gradonačelnika, odnosno načelnika općine. Tako se, pored ostalog, utvrđuje da gradonačelnik, odnosno načelnik općine, predlaže na razmatranje i usvajanje skupštini statut, budžet, odluke i druga opća akta, zatim, financijski izvještaj, ekonomske i razvojne planove i programe.

Općinski načelnik/gradonačelnik je prema ZLSRS-u zadužen i za provođenje lokalne politike, za odluke o izvršenju budžeta kao i za druge akte skupštine te zakone i druge propise čije provođenje je povjereno jedinici lokalne samouprave. Gradonačelnik/općinski načelnik također odlučuje o osnivanju gradske, odnosno općinske uprave i o unutrašnjoj organizaciji i sistematizaciji radnih mjesta gradske, odnosno općinske uprave. Pored toga, predlaže imenovanje i razrješenje načelnika odjeljenja ili službi i realizira suradnju jedinice lokalne samouprave sa drugim jedinicama lokalne samouprave, institucijama i organizacijama. ZLSRS utvrđuje nadležnost gradonačelnika odnosno načelnika općine i u drugim aktivnostima kao što je rješavanje po žalbama u drugom stupnju ako za rješavanje nisu nadležni republički organi, odlučivanje o sukobu nadležnosti između gradske, odnosno općinske uprave i organizacija koje vrše poslove od interesa za jedinicu lokalne samouprave.

Kada je riječ o organima općine, bitno je istaći da, u skladu sa ZLSRS-om, Narodna skupština RS može u određenim slučajevima raspustiti skupštinu općine. To se može desiti u slučaju kada se skupština ne konstituira u roku od tri mjeseca od potvrde izbornih rezultata; u slučaju kada se u određenom roku ne donese budžet; ako se ne održi sjednica skupštine u periodu od tri mjeseca. Skupština se također može raspustiti ako nakon što se provede postupak opoziva gradonačelnika/načelnik, općine isti ne bude opozvan. Ovakva mogućnost nije utvrđena u Federaciji BiH.

\subsection{ZAŠTITA PRAVA NA LOKALNU SAMOUPRAVU U RS}

Kako je to utvrđeno u članu 3. ZLSRS-a, lokalna samouprava ostvaruje se u gradovima i općinama, a izvršavaju je, pored organa jedinica lokalne samouprave, i građani. Dakle ovdje se, pored organa jedinica lokalne samouprave, utvrđuje da pravo na lokalnu samoupravu ostvaruju građani. To nije slučaj kod ZOPLS-a.

Zaštitu od povrede prava na lokalnu samoupravu osigurava nadležni sud (Ustavni sud RS). Taj postupak mogu pokrenuti organi jedinica lokalne samouprave kad god je nekim zakonom ili drugim općim aktom povrijeđeno prvo na lokalnu samoupravu. Također, ako organi jedinica lokalne samouprave smatraju da je nekim pojedinačnim aktom ili radnjom republičkog, odnosno državnog organa povrijeđeno pravo jedinice na lokalnu samoupravu mogu u roku od 30 dana od dana saznanja pred nadležnim okružnim sudom pokrenuti upravni spor. 


\section{DISTRIKT BRČKO BOSNE I HERCEGOVINE KAO JEDINICA LOKALNE SAMOUPRAVE}

\subsection{USTAVNOPRAVNI POLOŽAJ DB}

Prema Ustavu BiH (Amandman I), DB je pod suverenitetom BiH i u nadležnosti institucija $\mathrm{BiH}$. DB je zajednička svojina entiteta (kondominij) sa vlastitim institucijama, zakonima i drugim propisima i ovlaštenjima.

Ustav $\mathrm{BiH}$ utvrđuje da je DB jedinica lokalne samouprave i to je jedini slučaj u Ustavu BiH gdje se spominje lokalna samouprava.

Za DB je specifičan kako sam nastanak tako i organizacioni ustroj. Naime, DB je uspostavljen Odlukom ${ }^{17}$ Visokog predstavnika za $\mathrm{BiH}^{18}$ od 8. 3. 2000. godine, a na osnovu Konačne odluke Arbitražnog tribunala. Dakle, kako se u toku Dejtonskih mirovnih pregovora nije uspjelo riješiti pitanje područja prijeratne općine Brčko, rješavanje tog pitanja je odloženo. Tada je dogovoreno da se formira arbitražni sud čiju odluku će entiteti prihvatiti bezuvjetno. Tek 5. 3 . 1999. godine Tribunal je donio Konačnu odluku. ${ }^{19}$

\subsection{ORGANIZACIJA I NADLEŽNOSTI DB}

Statutom DB je utvrđena nadležnost na način da su taksativno pobrojane oblasti u kojima institucije vlasti DB vrše nadležnosti. Tako se u članu 8. Statuta DB utvrđuje nadležnost javnih organa vlasti u DB u oblasti privrede, financija; pružanja javnih usluga, zatim nadležnost za infrastrukturu, kulturu i obrazovanje. Također, nadležnost javnih organa vlasti u DB je Statutom DB utvrđena i u zdravstvenoj i socijalnoj zaštiti, zaštiti životne sredine. Pored navedenog nadležnost je utvrđena i za oblast pravosuđa, policije, urbanizma i prostornog planiranja.

$\mathrm{Za}$ razliku od drugih jedinica lokalne samouprave u $\mathrm{BiH}$, koje imaju načelnike/gradonačelnike kao inokosne izvršne organe i skupštine općine/općinska vijeća kao predstavničke organe (dakle, nisu zakonodavni organi), DB ima vladu kao kolegijalni izvršni organ i skupštinu kao zakonodavni organ. Vladu čini gradonačelnik, dogradonačelnik, glavni koordinator i šefovi odjeljenja.

Skupštinu DB čini 31 zastupnik koji su birani neposredno od strane građana DB na mandat od četiri godine. Skupština DB donosi statut, budžet, zakone odluke i druge akte; odlučuje o javnim zajmovima i zaduženju; vrši izbor i razrješenje predsjednika i potpredsjednika Skupštine DB i gradonačelnika, a daje i suglasnost na izbor zvaničnika DB; prati i ocjenjuje rad Vlade, uprave i ostalih institucija DB i ima i druge nadležnosti u skladu sa zakonom i Statutom DB.

17 Odluka Visokog predstavnika o uspostavi Distrikta Brčko Bosne i Hercegovine, Službene novine Federacije Bosne i Hercegovine, broj 13/2000.

18 Tadašnji Visoki predstavnik za BiH je bio Wolfgang Petritsch.

19 Konačnu odluku je ustvari donio - potpisao Roberts B. Oven kao predsjedavajući arbitar, a arbitri strana Ćazim Sadiković i Vitomir Popović nisu jer nisu postigli suglasnost. 
Gradonačelnika DB imenuje skupština i on obavlja svoju dužnost za vrijeme mandata skupštine. Gradonačelnik imenuje svog zamjenika, koordinatora Vlade i šefove odjeljenja. Zanimljivo je da je Statut DB ograničio broj savjetnika gradonačelnika na šest. To nije slučaj sa drugim gradonačelnicima i općinskim načelnicima koji taj broj utvrđuju u pravilnicima o sistematizaciji radnih mjesta. Gradonačelnik DB odgovara skupštini za provođenje zakona za rukovođenje $\mathrm{DB}$, podnosi nacrte zakona i daje prijedloge skupštini DB, predlaže budžet i obavlja druge dužnosti u skladu sa zakonom i Statutom.

Pored navedenih osobitosti koje DB kao jedinicu lokalne samouprave čine drugačijom u odnosu prema drugim jedinicama lokalne samouprave u BiH, treba navesti i to da DB ima vlastitu policiju, tužilaštvo i osnovni i apelacioni sud. Ovi organi nisu u nadležnosti jedinica lokalne samouprave koje su formirane na isključivoj teritoriji Federacije BiH i teritoriji RS.

\subsection{ZAŠTITA PRAVA NA LOKALNU SAMOUPRAVU U DB}

Ustav BiH u članu VI.4.2. propisuje nadležnost Ustavnog suda $\mathrm{BiH}$ da odlučuje o sporovima koji se tiču zaštite statusa i ovlaštenja DB, a koji se mogu javiti između entiteta i DB kao i između BiH i DB. Ovo podrazumijeva i zaštitu prava na lokalnu samoupravu. Ovakav spor, pred Ustavnim sudom $\mathrm{BiH}$, može pokrenuti većinom glasova skupština $\mathrm{DB}$, s tim da u toj većini mora biti najmanje jedna petina izabranih poslanika iz reda svakog konstitutivnog naroda.

\section{ULOGA I ZNAČAJ JEDINICA LOKALNE SAMOUPRAVE U BIH}

U BiH je Dejtonskim mirovnim sporazumom uspostavljen dosta složen i kompliciran sistem donošenja odluka. Ovaj sistem odlučivanja, a što je posljedica vremena u kojem je i načina na koji je Dejtonski mirovni sporazum kreiran i dogovaran (i značajno nametan), zasniva se na pristupu koji u svakom slučaju uključuje zaštitu nacionalnih interesa konstitutivnih naroda $\mathrm{BiH}$. Takvi su instrumenti zaštite, koje utvrđuje Ustav $\mathrm{BiH}$, primjerice institut zaštite vitalnih nacionalnih interesa i tzv. "entitetsko glasanje". Naravno, dodatno opterećenje donošenja odluka ogleda se u zloupotrebama navedenih instituta zaštite. To je potvrdio i Visoki predstavnik za BiH (High Representative) Valentin Inzko u svom obraćanju Vijeću sigurnosti Ujedinjenih naroda u studenom 2009. godine. ${ }^{20}$

Kada imamo u vidu složenost procesa odlučivanja koje je naročito izraženo na državnoj razini, a zatim i na entitetskoj razini, tj. u Federaciji BiH i nešto manje u Republici Srpskoj, i kada imamo u vidu disparatnost interesa na tim razinama, očitim postaju razlozi tromog kretanja BiH ka NATO-ovim i EU-ovim integracijama i slabog (sporog) napretka u reformskim procesima kako u oblasti uprave tako i u oblasti privrede, socijalne zaštite i dr.

20 Thirty-sixth report of the High Representative for Bosnia and Herzegovina, 1 May-31 October 2009, dostupno na: http://www. ohr.int/?p=35212. Pristupljeno 20. 2. 2017. godine. 
S druge strane, na dnu piramidalne strukture vlasti, smatramo, nalazi se ogroman, snažan i stabilan potencijal predstavljen u lokalnoj samoupravi. U BiH jedinice lokalne samouprave imaju utvrđene izuzetno značajne nadležnosti u čijem su opsegu, u manjoj ili većoj mjeri, gotovo sve oblasti svakodnevnih životnih potreba građana kao što je komunalna, stambena, socijalna, obrazovna (osnovno i predškolsko), zdravstvena, sigurnosna i dr.

Na toj razini vlasti uspostavljena je dosta homogena struktura općinskih/gradskih službi kojima u konačnici rukovodi inokosni organ općinski načelnik, odnosno gradonačelnik. Kroz ove strukture, uključujući i općinsko/gradsko vijeće (skupštinu općine u RS ili skupštinu u DB) provučene su u manjoj ili većoj mjeri sve aktivnosti kojima se izvršavaju nadležnosti jedinica lokalne samouprave. Tu se rješavaju konkretni zahtjevi građana, vode upravni postupci, provode upravne radnje, poduzimaju upravne mjere, planira, donose i izvršavaju odluke i drugi opći akti (čak i zakoni u DB), sažeto rečeno reguliraju konkretni, svakodnevni životni procesi (način života).

Financijski promatrano jedinice lokalne samouprave imaju dosta stabilan i značajan potencijal. Ukupno, prema podacima Centra za zastupanje građanskih interesa, ${ }^{21}$ za sve jedinice lokalne samouprave u $\mathrm{BiH}$, u 2015. godini budžetski prihodi su iznosili 1,599,218.826 KM (konvertibilnih maraka). ${ }^{22}$ Budžetski prihodi $\mathrm{BiH}$ (na državnoj razini) u toj godini iznosili su tek 967,539.094 KM.

Pravo na lokalnu samoupravu štite ustavni sudovi entiteta i Ustavni sud BiH. Značajan vid zaštite pružaju i kantonalni sudovi za jedinice lokalne samouprave iz Federacije BiH i okružni sudovi za jedinice lokalne samouprave iz RS. Pored 13 ustava u BiH i zakona na svim razinama, naročit značaj, kada je riječ o pravu na lokalnu samoupravu, ima EPLS. Međutim, reakcija organa koji su legitimirani da pokrenu postupak za zaštitu lokalne samouprave često izostane ili značajno kasni. Tako da propisi kojima se krši pravo na lokalnu samoupravu najčešće ostaju na snazi duži period. Tako je u postupku pred Ustavnim sudom Federacije BiH, u slučaju broj U-11/04 od 31. 5. 2005. godine, ${ }^{23}$ Zakon o komunalnim taksama koji je donesen 2001. godine osporen tek 2005. godine, a postupak je pokrenut 2004. godine. Ili u drugom slučaju broj U-4/11 od 17. 4. 2013. godine, ${ }^{24}$ Ustavni sud je utvrdio da je Srednjobosanski kanton povrijedio pravo općine Travnik jer nije osigurao sredstva za prijevoz učenika u skladu sa Zakonom o osnovnom školstvu koji je donesen 2001. godine.

Pored navedenog, naročito je značajno to što su jedinice lokalne samouprave kompaktniji sistemi koji u odnosu na više razine vlasti provode ujednačenije i usmjerenije svoje interesne aktivnosti kako unutar sistema tako i prema okolini.

U takvim sistemima uočavamo brojne mogućnosti organizacije i djelovanja koja mogu biti adekvatan odgovor i nadomjestak za određene slabosti sistema na višim razinama vlasti. Takvim pristupom izgradnje “odozdo" (bottom up) mogu se zaobići brojni kameni spoticanja koji otežavaju kretanje BiH naprijed, što je naročito primjetno u postizanju standarda kojima smo uvjetovani za priključenje još uvijek, za BiH, najprivlačnijim organizacijama: NATO-u i EU-u.

21 Centar za zastupanje građanskih interesa, http://javnefinansije.cpi.ba/budzetski-korisnici. Pristupljeno 16. 2. 2017. godine.

22 Što iznosi cca 820,112.218 eura.

23 Presuda broj U-11/04 od 31. 5. 2005. Službene novine Federacije Bosne i Hercegovine, broj 50/2005. 
Svakako, jedinice lokalne samouprave u BiH i pored brojnih nadležnosti i stabilnosti koju utvrđuju domaći i međunarodni akti, a njihovo provođenje osiguravaju prije svega ustavni sudovi, da bi postigli najbolji efekt moraju značajno unaprijediti organizaciju i procese kojima se ostvaruje lokalna samouprava. Naravno, to zahtijeva i konstantnu aktualizaciju i nadogradnju te organizacije i procesa čiju potrebu nameću zahtjevi iznutra (interesi građana) i vanjski uvjeti koji oblikuju načine zadovoljavanja tih interesa. Tako će se dosegnuti istinska demokracija, odnosno, kako ističe Zvonimir Lauc: “(...) sadržaji, oblici i procedure u kojima lokalni dužnosnici (lideri) postaju odgovorni građanima i gdje postaju osjetljivi na njihove potrebe i iščekivanja, jer se predmnijeva da načelo bliskosti osigurava moralnu, legitimnu i legalnu vlast. Upravo na toj razini ne bi smjelo biti većeg jaza između "Das Sollen" i "Das Sein”, gdje treba egzistirati intenzivna svakodnevna komunikacija između upravljača i upravljanih. Na toj razini ne bi smjelo biti mjesta za lakovjerni populizam, za korupciju i uske interese političkih elita." 25

Pored samoorganizacije jedinica lokalne samouprave mora postojati i podrška viših razina vlasti koja svoj odraz treba imati u što je moguće većem stupnju decentralizacije koja će sadržavati adekvatnu financijsku samostalnost (vlastiti izvori financiranja) i financijsku potporu u vidu raznih oblika doznačavanja sredstava naročito onim jedinicama lokalne samouprave koje imaju nedovoljne resurse i slabije prirodne, demografske i druge mogućnosti. Uz sve to, lokalna samouprava mora imati i adekvatnu zaštitu koja podrazumijeva ne samo mogućnost pokretanja postupka za zaštitu pred nadležnim sudovima, nego i potpuno i promptno provođenje odluka tih sudova. Suprotno tome, u BiH izvršavanje odluka ustavnih sudova nerijetko kasni ili se čak uopće i ne izvršava. To potvrđuje i veći broj rješenja Ustavnog suda Federacije $\mathrm{BiH}$ kojima je utvrđeno za pojedine odluke da nisu provedene. Primjerice, Rješenje Ustavnog suda Federacije BiH broj U-4/11 od 17. 4. 2013. godine, ${ }^{26}$ zatim, Rješenje Ustavnog suda Federacije $\mathrm{BiH}$, broj U-1/12 od 17. 4. 2013. godine ${ }^{27}$ ili Rješenje Ustavnog suda Federacije BiH, broj U-2/12 od 17. 4. 2013. godine. ${ }^{28}$ Međutim, iako je neprovođenje sudske odluke krivičnim zakonima $\mathrm{BiH}$ i entiteta utvrđeno kao krivično djelo, i dalje nema podignutih optužnica za neprovođenje sudske odluke kojom je utvrđena povreda prava na lokalnu samoupravu.

\section{ZAKLJUČAK}

$\mathrm{BiH}$ ima veoma složeno ustavnopravno uređenje koje podrazumijeva dva entiteta, jedan distrikt, deset kantona, 13 ustava i 14 zakonodavnih tijela sa vrlo značajnim nadležnostima i visokim stupnjem samostalnosti i neovisnosti od drugih/viših razina vlasti. Ovakvo uređenje je dodatno opterećeno mnogim otvorenim pitanjima sa nacionalnim, vjerskim i političkim

25 Lauc, Z., Odgovornost lokalne demokracije, Ustavna demokracija i odgovornost, HAZU, Zagreb, 2012., u Zborniku radova Moralitet legalitet - legitimitet, Sveučilište Josipa Jurja Strossmayera, Pravni fakultet u Osijeku, Osijek, 2016, str. 521.

26 Rješenje Ustavnog suda Federacije Bosne i Hercegovine, broj U-4/11 od 17. 4. 2013. godine, Službene novine Federacije Bosne i Hercegovine, broj 35/2013.

27 Rješenje Ustavnog suda Federacije Bosne i Hercegovine, broj U-1/12 od 17. 4. 2013. godine, Službene novine Federacije Bosne i Hercegovine, broj 35/2013.

28 Rješenje Ustavnog suda Federacije Bosne i Hercegovine, broj U-2/12 od 17. 4. 2013. godine, Službene novine Federacije Bosne i Hercegovine, broj 35/2013. 
predznakom. Sve to snažno opterećuje $\mathrm{BiH}$ i usporava u razvoju i u postizanju, zvanično ${ }^{29}$ jedinstvenog cilja- članstva u EU-u.

Međutim, kada je riječ o svakodnevnim potrebama ljudi, jasno je, obzirom na brojne i široko definirane nadležnosti jedinica lokalne samouprave, da je za njihovo zadovoljavanje najadekvatnije rješenje efikasan, efektivan i pristupačan sustav lokalne samouprave koja se ostvaruje u općinama i gradovima. Na toj se razini najmanje osjeti podijeljenost interesa i vjerujemo da lokalna samouprava u BiH može biti dobar odgovor na negativne posljedice tromog djelovanja viših razina vlasti. U svakom slučaju, pametno i moralno aktiviranje potencijala koji imaju jedinice lokalne samouprave u ljudskom (stručnom), organizacionom i financijskom smislu, mora polučiti značajnim i korisnim efektima koji se ogledaju u zadovoljnom korisniku (građaninu). To znači istinsku demokraciju i lokalnu samoupravu koja se može postići:

a) ustavnom i zakonskom garancijom značajnih nadležnosti

b) izdašnom i stabilnom financijskom stabilnošću

c) zagarantiranom (ustavom i zakonom) efektivnom i adekvatnom zaštitom

d) agilnom samoorganizacijom subjekata lokalne samouprave (građana i institucija) koja će značiti brz i efektivan odgovor na potrebe građana, brz i efektivan odgovor na prijetnje koje dolaze iznutra (koje produciraju elementi sistema: organi - neefektivna organizacija, neizvršavanje nadležnosti i dr.; pojedinci - korupcija i dr.) ili spolja kao što je povreda prava na lokalnu samoupravu od strane viših razina vlasti.

$\mathrm{Na}$ tom putu bi svakako bilo nužno izvršiti temeljitu analizu ovdje spomenutih pitanja kao što je teritorijalna reorganizacija jednog broja općina čiji su financijski i/ili ljudski kapaciteti oskudni te pitanje adekvatne zaštite lokalne samouprave, naročito u smislu provođenja presuda nadležnih sudova i eventualnog obeštećenja oštećenih jedinica lokalne samouprave.

Sve to zahtijeva ispravan poredak vrijednosti jer kako ističe Lauc: "Najbolja su rješenja poštena i pametna, unutar kojih se prepoznaje važnost: (1) moralnog kapitala, (2) intelektualnog, (3) socijalnog kapitala, (4) fizičkog kapitala i (5) financijskog kapitala."30

\section{LITERATURA}

1. Dmičić, M., Modernizacija, profesionalizam i usavršavanje lokalne samouprave u sistemu ustavnih promjena u BiH, Moderna uprava, Agencija za državnu upravu Republike Srpske, Banja Luka, 2008., str. 35.-55.

2. Ivanišević, S., Stupnjevanje lokalnih samoupravnih jedinica, Hrvatska javna uprava, broj 3, 2009., str. 669.-722.

3. Koprić, I., Prijedlozi za reformu lokalne i regionalne samouprave u Hrvatskoj, Hrvatska javna uprava, broj 4, 2010., str. 941.-959.

4. Lauc, Z., Odnos države i samouprave promatran kroz načelo supsidijarnosti, Anali Zavoda za znanstveni i umjetnički rad u Osijeku, sv. 26, 2010., str. 23.-36.

29 Vidi: Reformska agenda za Bosnu i Hercegovinu za period od 2015. do 2018. godine, dostupno na: http://www.fbihvlada.gov.ba/ pdf/Reformska\%20agenda.pdf. Pristupljeno 20. 2. 2017. godine.

30 Lauc, Zvonimir, Odnos države i samouprave promatran kroz načelo supsidijarnosti, Anali Zavoda za znanstveni i umjetnički rad u Osijeku, sv. 26, 2010., str. 23.-36. 
5. Lauc, Z., Odgovornost lokalne demokracije, Ustavna demokracija i odgovornost, HAZU, Zagreb, 2012., u Zborniku radova Moralitet - legalitet - legitimitet, Sveučilište Josipa Jurja Strossmayera, Pravni fakultet u Osijeku, Osijek 2016.

6. Pavić, Ž., Veličina lokalnih jedinica - europske tendencije i hrvatske nedoumice, Hrvatska javna uprava, broj 1, 2010., str. 81.-131.

\section{PROPISI I SUDSKE ODLUKE}

1. Ustav Bosne i Hercegovine, dostupno na: www.ohr.int/?page_id=68220. Pristupljeno 19. 2. 2017. godine.

2. Ustav Federacije Bosne i Hercegovine, Službene novine Federacije Bosne i Hercegovine, broj 1/1994, 13/1997, 16/2002, 22/2002, 52/2002, 63/2003, 9/2004, 20/2004, 33/2004, 71/2005, $72 / 2005,88 / 2008$.

3. Ustav Republike Srpske, Službeni glasnik Republike Srpske, broj 21/1992 - prečišćeni tekst, 28/1994, 8/1996, 13/1996, 15/1996, 16/1996, 21/1996, 21/2002, 26/2002, 30/2002, 31/2002, 69/2002, 31/2003, 98/2003, 115/2005, 117/2005.

4. Zakon o principima lokalne samouprave u Federaciji Bosne i Hercegovine, Službene novine Federacije Bosne i Hercegovine, broj 49/2006.

5. Zakon o lokalnoj samoupravi Republike Srpske, Službeni glasnik Republike Srpske, broj 97/2016.

6. Odluka Visokog predstavnika o uspostavi Distrikta Brčko Bosne i Hercegovine, Službene novine Federacije Bosne i Hercegovine, broj 13/2000.

7. Odluka Ustavnog suda BiH, U-5/98 od 1. 7. 2000. godine, Službene novine Federacije Bosne i Hercegovine, broj 15/2000.

8. Presuda, broj U-11/04 od 31. 5. 2005. Službene novine Federacije Bosne i Hercegovine, broj 50/2005.

9. Presuda, broj 4/11 od 27. 3. 2012. godine, Službene novine Federacije Bosne i Hercegovine, broj 38/2012.

10. Rješenje Ustavnog suda Federacije Bosne i Hercegovine, broj U-4/11 od 17. 4. 2013. godine, Službene novine Federacije Bosne i Hercegovine, broj 35/2013.

11. Rješenje Ustavnog suda Federacije Bosne i Hercegovine, broj U-1/12 od 17. 4. 2013. godine, Službene novine Federacije Bosne i Hercegovine, broj 35/2013.

12. Rješenje Ustavnog suda Federacije Bosne i Hercegovine, broj U-2/12, Službene novine Federacije Bosne i Hercegovine, broj 35/2013.

\section{MREŽNI IZVORI}

1. Centar za zastupanje građanskih interesa, http://javnefinansije.cpi.ba/budzetski-korisnici. Pristupljeno 16. 2. 2017. godine.

2. Reformska agenda za Bosnu i Hercegovinu za period od 2015. do 2018. godine, dostupno na: http://www.fbihvlada.gov.ba/pdf/Reformska\%20agenda.pdf. Pristupljeno 20. 2. 2017. godine.

3. Thirty-sixth report of the High Representative for Bosnia and Herzegovina, 1 May-31 October 2009, dostupno na: http://www.ohr.int/?p=35212. Pristupljeno 20. 2. 2017. godine. 


\section{LOCAL SELF-GOVERNMENT IN BOSNIA AND HERZEGOVINA}

\section{Summary}

The article gives a short review of local self-government in Bosnia and Herzegovina, specifically in the Federation of Bosnia and Herzegovina, Serbian Republic and the Brčko District of Bosnia and Herzegovina. The emphasis was on constitutional position of local self-government in Bosnia and Herzegovina, organization and jurisdiction of local governments and the legal instruments for the protection of rights on local self-government. The author deals with specific attributes of local self-government system in Bosnia and Herzegovina, the role and the importance of the local self-government in Bosnia and Herzegovina in creating a desirable living environment, as the level of government that is the closest to the citizens. Coherence of interests at local level, whose realization is under the jurisdiction of local self-governments units is pointed out as an advantage and a possible adequate response to the disparity of interests at the state level of government in Bosnia and Herzegovina. In conclusion, the author specifies certain preconditions to achievement of genuine local self-government.

Keywords: $\quad$ The Federation of Bosnia and Herzegovina, the Republic of Serbia, Brčko District, local self-government 